\title{
EDPS Opinion 10/2018 on the Commission: Package on free and fair European elections
}

The functioning of the Union is founded on representative democracy. Political communication is essential to the participation of citizens, political forces and candidates in democratic life and to the fundamental right to freedom of expression. These rights and freedoms are interdependent with the right to respect for private and family life, home and communications and the right the protection of personal data. Earlier this year, in his Opinion $3 / 2018$ on online manipulation, the EDPS highlighted the risks to fundamental rights of concentrated markets.

In the context of the 2018 State of the Union speech, the Commission presented a security package focusing on Free and fair European elections. This package is composed of a Communication, a Guidance document on the application of Union data protection law in the electoral context, a Recommendation and a proposal for a Regulation as regards a verification procedure related to infringements of rules on the protection of personal data in the context of elections to the European Parliament. The EDPS recognises the reference made to the role of social media platforms and on how this initiative would be coherent with the Code of Practice on online disinformation. In light of the upcoming European Parliament elections in May next year, and the numerous other national elections scheduled for 2019, the EDPS also recognises the recommendations for the setting up of national election networks and a European coordination network. ${ }^{1}$ He takes this opportunity to show his availability to participate in this European

1 https://edps.europa.eu/sites/edp/files/publication/18-12-18_opinion_on election_package_en.pdf network. It would complement EDPS action in this area, in particular the worskop which he organises in February next year. The EDPS also recognises the recommendation to Member States to perform a comprehensive assessment of risks associated with the elections to the European Parliament with a view to identifying potential cyber incidents that could affect the integrity of the electoral process and underlines the urgency of this matter.

In general, the EDPS considers that, for further clarity, a reference could have been included to the processing of personal data by the European Parliament, the Authority for European political parties and European political foundations and the Committee of independant persons, as being within the scope of Regulation 2018/1725 on the protection of natural persons with regard to the processing of personal data by the Union institutions, bodies, offices and agencies and on the free movement of such data (previously, Regulation 45/2001). In addition and more specifically, the EDPS makes several recommendations in relation to the proposed Regulation, among which clarifying the scope of the measures and the complementary aims of such sanctions, including EDPS decisions finding an infringement to Regulation 2018/1725 and a reference to the current data protection legal framework for cooperation between national data protection supervisory authorities and the EDPS as well as ensuring the confidentiality of the exchange of information in the context of the cooperation between data protection supervisory authorities and the Committee of independant persons.

\section{Springer}

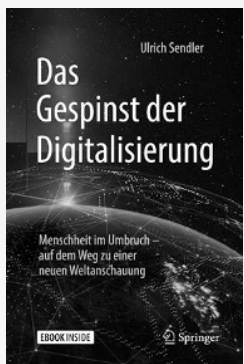

Ulrich Sendler

Das Gespinst der Digitalisierung

Menschheit im Umbruch - auf dem Weg zu einer neuen

Weltanschauung

2018, XXI, 298 S. Geb.

$€$ (D) $24,99|€(A) 25,58|{ }^{*} \mathrm{sFr} 25,50$

ISBN 978-3-658-21896-6

$€ 19,99$ * $^{*} \mathrm{SFr} 20,00$

ISBN 978-3-658-21897-3 (eBook)

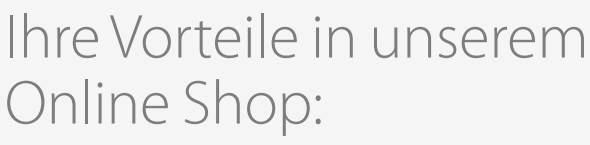

- Über 280.000 Titel aus allen Fachgebieten

- eBooks sind auf allen Endgeräten nutzbar

- Kostenloser Versand für Printbücher weltweit 